\title{
PRÁTICAS DE LEITURA E PRODUÇÃO DE TEXTOS NARRATIVOS, UTILIZÁVEIS COMO RECURSO ARGUMENTATIVO
}

Douglas Geraldo da Costa (UNICSUL)

Vinculado à linha de pesquisa Texto discurso e ensino: processos de leitura e produção de texto escrito e falado e ao grupo de pesquisa Teorias e práticas discursivas e textuais, o presente trabalho tem por objetivo a apresentação de pesquisa em desenvolvimento cujo escopo é: práticas de leitura e produção de textos narrativos, utilizáveis como recurso argumentativo. As práticas contemplam as sequências textuais narrativas, descritivas, expositivas e argumentativas (Adam, 2011), além dos preceitos metodológicos do Ensino Público; em questão, o mineiro. O Ensino público prioriza a identificação, análise e produção dos gêneros e tipos textuais próprios ao aprendiz produtor de textos, conforme a série / ciclo em curso. O Corpus de análise constitui-se de produções textuais narrativas, de alunos da rede pública mineira; as análises visam verificar como os postulados da Análise Textual dos Discursos, postulada por Adam (2011), especialmente os conceitos relativos às sequências narrativas, descritivas, expositivas e argumentativas podem fundamentar estratégias que levem o aprendiz produtor de textos a construir narrativas como elemento embasador para a escrita de textos dissertativos-argumentativos. As análises explorarão, através das sequências, como estas estruturam o discurso narrativo com vistas ao argumentativo, a partir da ATD - teoria embasadora deste projeto.

Palavras-chave: narração - sequências - argumentação. 